\title{
PENERAPAN MODEL LEARNING CYCLE 5E \\ UNTUK MENINGKATKAN PEMBELAJARAN IPA
}

(Penelitian Tindakan Kelas di Kelas IV SDN Pancasila Kecamatan Lembang Kabupaten Bandung Barat Pada Pokok Bahasan Perubahan Lingkungan Fisik)

\author{
Oleh : Yuyu Yuliatii ${ }^{1}$ \\ Yuyuliati74@gmail.com
}

\begin{abstract}
ABSTRAK
Penelitian ini berangkat dari permasalahan pembelajaran di SDN Pancasila kecamatan Lembang Kabupaten Bandung Barat, dimana dalam pembelajaran keterlibatan siswa secara aktif dalam pembelajaran masih tergolong rendahUntuk mengatasi permasalah tersebut peneliti melakukan penelitian penerapan model learning cycle $5 E$ untuk meningkatkan pembelajaran IPA. Penelitian ini bertujuan untuk mengetahui perencanaan, pelaksanaan dan peningkatan pembelajaran IPA dengan menggunakan model learning cycle 5E. Metode penelitian yang digunakan adalah penelitian tindakan kelas (PTK) yang terdiri dari dua siklus. Untuk mengetahui pelaksanaan dan hasil belajar, digunakan teknik pengambilan data dengan observasi dan tes yang dilakukan tiap akhir siklus. Instrumen yang digunakan adalah lembar observasi dan tes tertulis. Hasil penelitian menunjukkan 1) Pelaksanaan pembelajaran, siswa cenderung lebih aktif dalam pembelajaran, 2) Proses pembelajaran dan hasil belajar siswa mengalami peningkatan, ditunjukan dengan adanya peningkatan aktivitas siswa pada setiap fase pembelajaran, dari kelima fase rata-rata aktivitas siswa pada siklus I 62,53\% dan pada siklus II meningkat menjadi $86,83 \%$. Peningkatan hasil belajar untuk aspek kognitif CI-C3 diukur melalui tes untuk siklus I jumlah siswa tuntas mencapai $60,52 \%$ dan meningkat pada siklus II menjadi 94,73\%. Untuk aspek afektif dan psikomotor diukur melalui kegiatan observasi melalui lembar penilaian kinerja, pada siklus I jumlah siswa yang mencapai KKM 92,10\% dan meningkat pada siklus II menjadi $100 \%$. Secara umum dapat disimpulkan bahwa penerapan model learning cycle $5 E$ terbukti dapat meningkatkan pembelajaran IPA di kelas IV SDN Pancasila Kecamatan Lembang Kabupaten Bandung Barat.
\end{abstract}

Kata Kunci: Model Learning Cycle 5e, Pembelajaran, IPA,

\footnotetext{
1Penulis adalah Dosen Tetap pada Prodi PGSD Fakultas Pendidikan Dasar dan Menengah Universitas Majalengka
} 


\section{Pendahuluan}

IPAmerupakan salah satu mata pelajaran yang membahas tentang gejala-gejala alam yang disusun secara sistematis dan menuntut keterlibatan siswadalam proses pembelajarannya. Dalam Kurikulum Tingkat Satuan Pendidikan (KTSP), dijelaskan bahwa IPA bukan hanya penguasaan kumpulan pengetahuan yang berupa fakta-fakta, konsep-konsep, atau prinsip-prinsip saja tetapi juga merupakan suatu proses penemuan. Proses pembelajaran IPA menekankan pada pemberian pengalaman langsung melalui penggunaan dan pengembangan keterampilan proses dan sikap ilmiah untuk mengembangkan kompetensi agar menjelajahi dan memahami alam sekitar secara ilmiah melalui kegiatan inkuiri.

Berdasar pada penjelasan KTSP tersebut, maka berimplikasi pada pembelajaran IPA di kelas. Materi IPA tidak hanya terdiri atas kumpulan fakta, konsep, prinsip dan hukum yang dihafal, akan tetapi belajar IPA juga belajar tentang cara memperoleh informasi tentang IPA, cara sains dan teknologi bekerja dalam bentuk pengetahuan prosedural, termasuk kebiasaanbekerja ilmiah dengan metode dan sikap ilmiah yang dikembangkan berdasarkan pengalaman langsung dan kegiatan kongkret. Oleh karena itu, mata pelajaran IPA tidak dapat diberikan dengan hanya ceramah saja akan tetapi harus didasarkan pada pengalaman siswa terlibat langsung secara aktif dalam kegiatan kongkret untuk memperoleh informasi, dengan keterlibatan siswa secara aktif tersebut diharapkan siswa dapat membangun sendiri pengetahuannya.

Kenyataan yang terjadi di lapangan masih belum sesuai dengan yang diharapkan. Pada kenyataannya saat ini, masih banyak guru belum mampu mengembangkan pembelajaran yang berorientasi pada siswa aktif sehingga masih sedikit siswa yang terlibat aktif ketika proses pembelajaran berlangsung. (edukasi.kompasiana.com/2010/10/15/pendid ikan-budaya-dan-entrepreneurship/). Hal ini diasumsikan dapat berakibat pada hasil belajar siswa yang tidak begitu memuaskan. Uzer dalam (Yuliani, 2006:7) berpendapat bahwa dalam menciptakan kondisi belajar mengajar yang efektif setidaknya ada lima variabel yang menentukan keberhasilan belajar siswa yaitu melibatkan siswa secara aktif, menarik minat dan perhatian siswa, membangkitkan motivasi siswa, memperhatikan kemampuan siswa dan menggunakan alat peraga yang tepat.

Hal tersebut jugaterjadi pada pembelajaran IPA di SDN Pancasila Kabupaten Bandung Barat. Berdasarkan hasil observasi pendahuluan pada pembelajaran IPA, aktivitas yang menunjukan siswa aktif dalam proses pembelajaran masih tergolong rendah. Hal ini terlihat ketika proses pembelajaran hanya sebagian kecil siswa yang berpartisipasi langsung dalam pembelajaran, siswa lebih banyak diam dan menunggu penjelasan dari guru, terdapat beberapa orang siswa yang tidak fokus ketika proses pembelajaran dan melakukan aktivitas lain yang tidak relevan dengan aktivitas belajar, diantaranya mengobrol dengan teman sebangku atau bahkan bermain-main.

Selain itu sebagian besar siswa masih kesulitan mengkomunikasikan hasil belajarnya, ini terlihat ketika pembelajaran berlangsung sebagian besar siswa terutama siswa yang prestasi belajarnya rendah komunikasi yang ditampilkan siswa ketika proses pembelajaran masih belum lancar. Siswa masih kesulitan mengungkapkan pendapat, gagasan yang disampaikan masih belum jelas dan belum bisa mempresentasikan hasil pengamatan dengan baik. Hal ini ditunjang dengan jarang sekali guru menggunakan model pembelajaran yang bervariatif dan berpusat pada siswa, kegiatan demonstrasi atau percobaan yang menghadirkan fenomena-fenomena IPA jarang dilakukan. Maka dari itu, peneliti berasumsi bahwa hal ini berdampak pada kualitas pembelajaran IPA yang masih 
rendah sehingga berujung pada hasil belajar siswa yang belum memuaskan. Pada mata pelajaran IPA perolehan hasil belajar siswa pada ujian tengah semester didapat hanya 8 orang siswa atau21,05\% dari keseluruhan siswa yang mendapatkan nilai diatas nilai KKM sebesar 65 sedangkan siswa lainnya sebesar 78,94\% masih mendapatkan nilai dibawah nilai KKM.

Berdasarkan data diatas, analisis observasi terhadap pembelajaran diantaranya bahwa proses pembelajaran tidak melibatkan siswa secara aktif dalam membangun sendiri pengetahuannya sehingga yang terjadi adalah transfer pengetahuan dari guru kepada siswa yang hanya satu arah, sehingga siswa hanya diam dan menunggu penjelasan dari guru. Hal ini menunjukan kualitas pembelajaran yang cenderung masih rendah.Sehingga menyebabkan pembelajaran yang dialami oleh siswa kurang bermakna dan hasil belajar yang ditampilkan kurang begitu memuaskan. Hasil tes yang belum memuaskan menggambarkan hasil belajar pada aspek kognitif siswa masih rendah. Selain itu kurangnya keaktifan siswa dalam pembelajaran menggambarkan hasil belajar pada aspek psikomotor dan afektif siswa dalam proses pembelajaran juga rendah.

Alternatif yangdapat digunakan untuk pemecahan masalah tersebut diantaranya dengan penggunaan model pembelajaran yang melibatkan siswa secara langsung dan terlibat aktif dalam membangun sendiri pengetahuannya. Salah satu model pembelajaran yang dianggap sesuai adalah model Learning Cycle. Model Learning Cycleadalah model pembelajaran yang berlandaskan pada pandangan konstruksivisme yang tentunya berpusat pada siswa (student centered), Learning Cycle merupakan rangkaian tahap-tahap kegiatan yang diorganisasi sedemikian rupa sehingga siswa dapat menguasai kompetensikompetensi yang harus dicapai dalam pembelajaran dengan jalan berperan aktif. Beberapa study tentang implementasi Learning Cycledalam pembelajaran
sains(Budiasih dan Widarti, 2004; Fajaroh dan Dasna, 2004) bahwa penggunaan Learning Cycle menunjukkan keberhasilan dalam meningkatkan kualitas proses dan hasil belajar siswa. Model Learning Cycle yang digunakan dalam penelitian ini adalah model Learning Cycle dengan 5 tahapan. Tahapan pada Learning Cycle5E yaitu : engage, explore, explain, extend, dan evaluate sesuai yang diungkapkan olehLorsbach (dalam Fajaroh, 2008).

Berdasarkan latar belakang di atas, penulis tertarik untuk mencoba melakukan penelitian terkait dengan efektifitas model pembelajaran learning cycle dalam meningkatkan pembelajaran IPA. Adapun permasalahan yang akan diteliti dalam penelitian mencakup bagaimana perencanaan, pelaksanan model pembelajaran learning cycle dan apakah model learning cycledapat meningkatkan pembelajan IPA.

\section{Pembelajaran IPA di SD}

Dimyati \& mudjiono (dalam, sagala 2010:62) menjelaskan bahwa "Pembelajaran adalah kegiatan guru secara terprogram dalam desain instruksional untuk membuat siswa belajar secara aktif yang menekankan pada penyediaan sumber belajar". Pembelajaran mempunyai dua karakteristik yaitu, dalam proses pembelajaran melibatkan proses mental siswa secara maksimal, dan membangun suasana dialogis dan proses tanya jawab terus menerus yang diarahkan untuk memperbaiki dan meningkatkan kemampuan berfikir siswa, yang pada gilirannya kemampuan berfikir itu dapat membantu siswa untuk memperoleh pengetahuan yang mereka konstruksi sendiri.

Mulyasa (2005:174)mengemukakan bahwa kualitas pembelajaran dapat dilihat dari segi proses dan dari segi hasil pembelajaran dan dikatakan berhasil apabila tercapai seluruhnya atau setidak-tidaknya 75\%,sebagaimana dikemukakan: "Dari segi proses, pembelajaran dikatakan berhasil dan berkualitas apabila seluruhnya atau setidak- 
tidaknya sebagian besar $(75 \%)$ peserta didik terlibat aktif, baik fisik, mental maupun social dalam proses pembelajaran, disamping menunjukan kegairahan belajar yang tinggi, semangat belajar yang besar, dan rasa percaya pada diri sendiri. Sedangkan dari segi hasil, proses pembelajaran dikatakan berhasil apabila terjadi perubahan tingkah laku yang positif pada diri peserta didik apabila seluruhnya atau setidak-tidaknya sebagian besar (75\%)".

Dari penjelasan tersebut jelaslah bahwa suatu pembelajaran dapat dikatakan berhasil dan berkualitas apabila keterlibatan siswa secara aktif dalam proses pembelajaran sebanyak minimal $75 \%$ dari keseluruhan jumlah siswa.

Pada hakikatnya IPA dibangun atas dasar produk ilmiah, proses ilmiah dan sikap ilmiah (Trianto, 2010:137).IPA sebagai proses maksudnya adalah proses untuk mandapatkan IPA itu sendiri melalui suatu proses atau metode Ilmiah. Metode ilmiah meliputi penyusunan hipotesis, perancangan eksperimen atau percobaan, evaluasi, pengukuran dan penarikan kesimpulan. Proses IPA merupakan cara kerja memperoleh hasi-hasil. IPA tidak hanya fakta tetapi juga proses yang terdiri dari cara kerja, sikap, dan cara berfikir karena itu sering dikatakan bahwa proses mendapatkan IPA merupakan bagian IPA yang tidak dapat dipisahkan dari IPA itu sendiri.

Hakekat IPA sebagai produk diartikan sebagai hasil proses, berupa pengetahuan yang diajarkan dalam sekolah atau di luar sekolah ataupun bahan bacaan untuk penyebaran pengetahuan yang terdiri terdiri dari fakta (sesuatu yang dapat dibuktikan kebenarannya), konsep (kumpulan dari faktafakta yang berkaitan), prinsip, teori dan hukum.

Ketiga unsur itu merupakan ciri IPA yang utuh yang sebenarnya tidak dapat dipisahkan satu sama lain. Sehingga dalam proses pembelajaran IPA ketiga unsur itu diharapkan dapat muncul, sehingga siswa dapat mengalami proses pembelajaran secara utuh dan bermakna.

\section{Model Learning Cycle}

Learning cycle merupakan model pembelajaran yang berpusat pada siswa (student centered) dan berlandaskan pada pandangan konstruksivisme dari piaget. Learning cyclejuga dapat dijelaskan sebagai rangkaian tahap-tahap kegiatan (fase) yang diorganisasi sedemikian rupa sehingga siswa dapat menguasai kompetensi-kompetensi yang harus dicapai dalam pembelajaran dengan jalan berperanan aktif.Learning Cycle merupakan model pembelajaran yang dikembangkan oleh Karplus dan Their sesuai dengan pandangan Piaget. Dalam hal ini siswa diberi kesempatan untuk mengasimilasi informasi dengan cara mengeksplorasi lingkungan, mengakomodasi informasi dengan cara mengembangkan konsep, mengorganisasikan informasi dan menghubungkan konsep-konsep baru dengan menggunakan atau memperluas konsep yang dimiliki untuk menjelaskan suatu fenomena yang berbeda.

Sebagaimana dikemukakan oleh Lorsbach (dalam Fajaroh, 2008) bahwa "Learning Cycle dengan lima tahapan sering dijuluki LC $5 E$ yaitu Engagement, Exploration, Explaination, Elaboration, dan Evaluation."

Pada model learning cycle 5E, tahapan pada siklusnya tidak berakhir pada siklus terakhir.Setelah elaborasi berakhir, keterlibatan siklus belajar berikutnya dimulai, tahap evaluasi bukan merupakan tahapan terakhir melainkan evaluasi terjadi disemua empat bagian dari siklus pembelajaran.

Kelima tahapan tersebut dapat dijelaskan lebih lanjut sebagai berikut:

\section{Engagement}

Tahap ini bertujuan untuk mempersiapkan diri siswa supaya terkondisi dalam menempuh tahap pembelajaran 
berikutnya dengan cara mengeksplorasi pengetahuan awal dan ide-ide siswa serta bertujuan untuk mengetahui kemungkinan terjadinya miskonsepsi pada pembelajaran sebelumnya. Dalam tahap ini minat dan keingintahuan (curiosity) siswa tentang topik yang akan diajarkan berusaha dibangkitkan selain itu siswa diajak membuat prediksiprediksi tentang fenomena yang akan dipelajari dan dibuktikan dalam tahap eksplorasi.

\section{Exploration}

Pada tahap exploration, siswa diberi kesempatan untuk bekerja sama dalam kelompok-kelompok kecil tanpa pengajaran langsung dari guru untuk menguji prediksi, melakukan dan mencatat pengamatan serta ide-ide melalui kegiatan-kegiatan seperti praktikum dan telah literatur.

\section{Explaination}

Pada fase explanation, guru mendorong siswa untuk menjelaskan konsep dengan kalimat mereka sendiri, meminta bukti dan klarifikasi dari penjelasan mereka, dan mengarahkan kegiatan diskusi. Pada tahap ini siswa menemukan istilah-istilah dari konsep yang dipelajari.

\section{Elaboration}

Pada fase elaboration (extention), siswa menerapkan konsep dan ketrampilan dalam situasi baru melalui kegiatan-kegiatan seperti praktikum lanjutan dan problem solving.

\section{Evaluation}

Pada tahap akhir, yaitu fase evaluation dilakukan evaluasi terhadap efektifitas tahaptahap sebelumnya dan juga evaluasi terhadap pengetahuan, pemahaman konsep, atau kompetensi siswa melalui problem solving dalam konteks baru yang kadang-kadang mendorong siswa melakukan investigasi lebih lanjut.

Apabila kelima tahapan tersebut digambarkan dalam bentuk siklus, maka dapat ditampilkan seperti di bawah ini (Lorsbach, 2008).

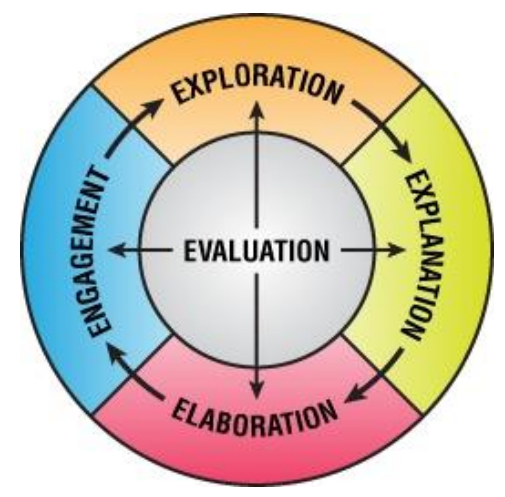

Gambar 1.

Tahapan learning cycle 5E

\section{Metode}

Penelitian ini dilaksanakan di kelas IV SDN Pancasila yang beralamat di jalan Peneropongan Bintang No.52 Desa Gudangkahuripan Kecamatan Lembang Kabupaten Bandung Barat. Adapun subjek penelitian dalam penelitian ini yaitu siswa kelas IV SD Negeri Pancasila yang terdiri dari 38 orang siswa, 23 orang siswa laki-laki dan 15 orang siswa perempuan.

Metode yang digunakan dalam penelitian ini yaitu metode penelitian tindakan kelas (Class Room Action).Model penelitian tindakan kelas (PTK) yang digunakan dalam penelitian ini adalah model daur siklus yang dikembangkan oleh Kemmis dan Mc Taggart (1988). Model ini mencakup empat komponen, yaitu: rencana (planning), tindakan (action), observasi (observation) dan refleksi (reflection). 
Siklus PTK

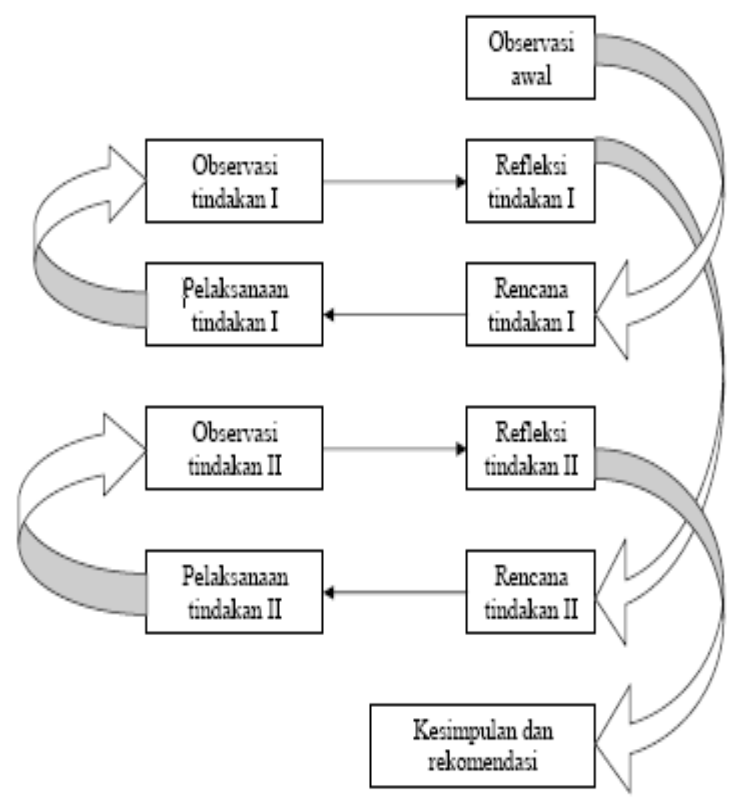

Gambar 2.

Model Siklus PTK dari Kemmis dan Taggart (1988)

Pengertian siklus pada kesempatan ini adalah satu putaran kegiatan yang terdiri dari perencanaan (planning), tindakan (action), observasi (observation) dan refleksi (reflection). Untuk pelaksanaan penelitian sesungguhnya, jumlah siklus sangat bergantung pada permasalahan yang akan diselesaikan. Apabila tujuan penelitian belum tercapai maka penelitian akan dilanjutkan pada siklus selanjutnya, namun sebaliknya apabila tujuan penelitian sudah tercapai maka penelitian dihentikan setelah siklus terakhir selesai.

\section{Hasil dan Pembahasan Siklus 1}

Berdasarkan pengamatan dari tiap siklus, penggunaan model learning cycle pada saat pembelajaran semakin meningkat. Keterampilan peneliti dalam setiap pembelajaran semakin baik.Hal ini dapat dilihat dari hasil observasi keterlaksanan model pembelajaran yang mana pada siklus 1 ada beberapa kegitan yang belum terlaksana seperti tidak menjelaskan dampak erosi dan tidak melakukan refleksi namun pada siklus 2 semuanya sudah terlaksana.
Selain pengamatan pada guru, pengamatan juga dilakukan pada siswa untuk mengamati aktivitas siswa selama proses pembelajaran. Proses pembelajaran tercermin dari rata-rata aktivitas siswa pada setiap fase pembelajaran. Untuk siklus 1 Persentase aktivitas siswa pada setiap fase pembelajaran diuraikan dalam tabel berikut :

Tabel: 1

Rekapitulasi aktivitas siswa pada siklus 1

\begin{tabular}{|l|l|l|l|}
\hline No & $\begin{array}{l}\text { Fase } \\
\text { learning } \\
\text { cycle 5E }\end{array}$ & $\begin{array}{l}\text { Rata-rata } \\
\text { persentase } \\
\text { aktivitas } \\
\text { siswa }\end{array}$ & Kategori \\
\hline 1. & Fase Engage & 57,0 & Cukup \\
\hline 2. & Fase Explore & 100,0 & Sangat Baik \\
\hline 3. & Fase Explain & 74,99 & Baik \\
\hline 4. & Fase Extend & 31,57 & Sangat kurang \\
\hline 5. & $\begin{array}{l}\text { Fase } \\
\text { Evaluate }\end{array}$ & 42,10 & Kurang \\
\hline $\begin{array}{l}\text { Rata-rata aktivitas } \\
\text { siswa siklus I }\end{array}$ & 61,53 & Cukup \\
\hline
\end{tabular}

Dari kelima fase pembelajaran tersebut aktivitas siswa dapat dirata-ratakan $61,53 \%$ dengan kategori cukup. Aktivitas siswa pada siklus I dapat dikatakan masih tergolong rendah karena belum mencapai $75 \%$. Proses pembelajaran selain dilihat dari rata-rata aktivitas siswa pada setiap fase pembelajaran juga dilihat dari berapa banyak siswa yang aktif selama proses pembelajaran. Siswa dikatakan aktif apabila siswa ikut terlibat aktif melaksanakan tahapan $\geq 75 \%$ dari keseluruhan tahapan pembelajaran. Berdasarkan data hasil observasi, jumlah siswa aktif pada pembelajaran siklus I hanya 10 orang siswa dengan rata-rata $26,31 \%$ dari keseluruhan jumlah siswa.

Hasil belajar siswa pada siklus 1 diperoleh melalui tes tertulis yang dilaksanakan pada akhir siklus.Sedangkan hasil belajar siswa pada aspek afektif dan psikomotor diperoleh dari kegiatan observasi penilaian kinerja ketika melakukan percobaan.Hasil tes kognitif dan hasil penilaian kinerja siswa pada siklus I diuraikan dalam tabel berikut : 
Tabel 2

Rekapitulasi hasil belajar siswa siklus 1

\begin{tabular}{|l|l|c|}
\hline $\begin{array}{l}\text { Hasil belajar } \\
\text { siswa }\end{array}$ & $\begin{array}{l}\text { Siswa tunta } \\
(\mathrm{KKM} \geq 65)\end{array}$ & $\%$ \\
\hline Tes kognitif & 23 orang & $60,52 \%$ \\
\hline $\begin{array}{l}\text { Penilaian } \\
\text { kinerja }\end{array}$ & 35 orang & $92,10 \%$ \\
\hline
\end{tabular}

Berdasarkan data yang diperoleh pada siklus I, untuk keterlaksanaan model pembelajaran baik oleh guru maupun oleh siswa masih belum terlaksana secara maksimal. Hal ini dikarenakan aktivitas siswa pada fase engage, extend, dan evaluate belum mencapai $75 \%$. Untuk proses pembelajaran rata-rata aktivitas siswa dari kelima fase pembelajaran baru mencapai $61,53 \%$ sedangkan jumlah siswa aktif hanya 10 orang, sementara indikator keberhasilan dalam penelitian ini adalah proses pembelajaran dikatakan meningkat apabila rata-rata aktivitas siswa dan keterlaksanaan tahapan pembelajaran mencapai $75 \%$ dan jumlah siswa aktif mencapai $75 \%$ dari keseluruhan jumlah siswa. Untuk hasil belajar siswa jumlah siswa tuntas untuk hasil tes kognitif yaitu berjumlah 23 orang $(60,52 \%)$ sedangkan jumlah siswa tuntas untuk penilaian kinerja berjumlah 35 orang $(92,10 \%)$ sementara indikator keberhasilan dalam penelitian ini adalah $85 \%$ siswa tuntas dalam pembelajaran.

Dengan demikian kriteria keberhasilan penelitian pada siklus I baik keterlaksanaan model pembelajaran, proses pembelajaran maupun hasil belajar masih belum tercapai karena masih dibawah kriteria keberhasilan penelitian.Oleh karena itu, diperlukan tindakan perbaikan pada siklus II.

\section{Siklus 2}

Berdasarkan data hasil observasi, terjadi peningkatan keterlaksanaan tahapan pembelajaran oleh guru. Pada siklus I keterlaksanaan tahapan pembelajaran belum seluruhnya terlaksana, namun pada siklus II tahapan pembelajaran telah seluruhnya dilaksanakan oleh guru.Peningkatan bukan hanya terjadi pada keterlaksanaan tahapan melainkan juga terjadi pada proses pembelajaran. untuk siklus II Persentase aktivitas siswa pada setiap fase pembelajaran diuraikan dalam tabel berikut:

Tabel 3

Rekapitulasi aktivitas siswa pada siklus II

\begin{tabular}{|l|l|l|l|}
\hline $\begin{array}{l}\text { No } \\
\text { cycle 5E }\end{array}$ & $\begin{array}{l}\text { Fase learning } \\
\text { cyata-rata }\end{array}$ & $\begin{array}{l}\text { Kategori } \\
\text { aktivitas } \\
\text { siswa (\%) }\end{array}$ & $\begin{array}{l}\text { Sangat } \\
\text { Baik }\end{array}$ \\
\hline 1. & Fase Engage & 82,45 & $\begin{array}{l}\text { Sangat } \\
\text { Baik }\end{array}$ \\
\hline 2. & Fase Explore & 95,61 & $\begin{array}{l}\text { Sangat } \\
\text { Baik }\end{array}$ \\
\hline 3. & Fase Explain & 92,10 & Baik \\
\hline 5. & Fase Extend & 79,82 & $\begin{array}{l}\text { Sangat } \\
\text { Baik }\end{array}$ \\
\hline $\begin{array}{l}\text { Rata-rata aktivitas } \\
\text { siswa pada siklus II }\end{array}$ & 84,21 & $\begin{array}{l}\text { Sangat } \\
\text { Baik }\end{array}$ \\
\hline
\end{tabular}

Secara keseluruhan aktivitas siswa pada siklus II jauh lebih baik bila dibandingkan siklus I. Hal ini terlihat pada setiap tahapan pembelajaran sudah hampir seluruhnya siswa terlibat aktif. Jika dibandingkan dengan siklus $I$, terdapat kenaikan presentase keterlibatan siswa yang cukup signifikan, terutama pada fase engage, extend, dan evaluate. Hampir seluruh fase pada pembelajaran siklus I dan II mengalami peningkatan hanya pada fase explore keterlibatan siswa mengalami sedikit penurunun. Peningkatan yang sangat signifikan terjadi pada fase extend dan evaluate. Masing-masing fase memiliki ratarata aktivitas siswa $79,82 \%$ untuk fase extend dan $84,21 \%$ untuk fase evalute.

Proses pembelajaran selain dilihat dari rata-rata aktivitas siswa pada setiap fase pembelajaran juga dilihat dari berapa banyak siswa yang aktif selama proses pembelajaran. Berdasarkan data hasil observasi aktivitas siswa pada proses pembelajaran jumlah siswa aktif pada pembelajaran siklus II mencapai 30 orang dengan persentase $74,94 \%$ dari keseluruhan jumlah siswa. kognitif dan hasil penilaian kinerja siswa pada siklus II diuraikan dalam tabel 4 berikut: 
Tabel 4

Rekapitulasi hasil belajar siswa pada siklus II

\begin{tabular}{|l|l|l|}
\hline $\begin{array}{l}\text { Hasil belajar } \\
\text { siswa }\end{array}$ & $\begin{array}{l}\text { Jumlah siswa } \\
\text { tuntas } \\
\text { (mencapai } \\
\text { KKM) }\end{array}$ & $\begin{array}{l}\text { \% siswa } \\
\text { tuntas } \\
\text { (mencapai } \\
\text { KKM) }\end{array}$ \\
\hline Tes kognitif & 36 orang & $94,73 \%$ \\
\hline $\begin{array}{l}\text { Penilaian } \\
\text { kinerja }\end{array}$ & 38 orang & $100 \%$ \\
\hline
\end{tabular}

Tercapainya kriteria keberhasilan penelitian pada siklus II baik dari segi pelaksanaan model dalam pembelajaran, proses pembelajaran yang meliputi aktivitas guru dan siswa, serta hasil belajar siswa pada aspek kognitif, afektif dan psikomotor menunjukan bahwa penelitian tindakan kelas ini dapat dikatakan berhasil dan berakhir pada siklus II.

Berdasarkan uraian data hasil penelitian di atas maka dapat dijelakan bahwa terdapat peningkatan hasil belajar dan aktivitas siswa dalam proses pembelajaran yang telah mencapai lebih dari $75 \%$ setelah diterapkannya model learning cycle $5 E$. Mulyasa (2005:174)mengemukakan bahwa kualitas pembelajaran dapat dilihat dari segi proses dan dari segi hasil pembelajaran, proses pembelajaran dikatakan berhasil apabila seluruhnya atau setidak-tidaknya $75 \%$ siswa terlibat aktif dalam proses pembelajaran, adanya peningkatan aktivitas dan hasil belajar tersebut menunjukan bahwa penerapan model learning cycle 5Eterbukti dapat meningkatkan pembelajaran IPA

Pembelajaran IPA di SD menekankan pada pemberian pengalaman belajar secara langsung melalui penggunaan dan pengembangan keterampilan proses dan sikap ilmiah. Pembelajaran dengan menggunakan model learning cycle $5 E$ yang pada pengimplementasiannya menitik beratkan pada keterlibatan siswa secara langsung sedangkan guru hanya berperan sebagai fasilitator. Keterlibatan siswa secara aktif pada setiap tahapan pembelajaran model learning cycle5E selain sesuai dengan tuntutan KTSP ternyata juga sesuai dengan pandangan konstruktivisme dari piaget. Suparno dalam (Trianto, 2010:75) menyebutkan bahwa prinsip-prinsip pembelajaran berdasar pada pandangan konstruktivisme antara lain pengetahuan dibangun oleh siswa secara aktif, tekanan dalam proses belajar terletak pada siswa, mengajar adalah membantu siswa belajar. Dengan keterlibatan siswa secara aktif baik fisik maupun mental diharapkan pembelajaran akan lebih bermakna bagi siswa dan tentunya diharapkan dapat meningkatkan hasil belajar siswa.

Hasil penelitian yang menunjukan adanya peningkatan proses dan hasil belajar siswa ternyata memiliki persamaan hasil dengan penelitian yang telah dilakukan oleh Fajaroh dan Dasna (2004) yaitu bahwa penerapan model learning cycle $5 E$ dalam pembelajaran IPA dapat meningkatkan proses pembelajaran dan hasil belajar siswa.

Berdasarkan uraian tersebut, dapat disimpulkan bahwa model learning cycle $5 E$ dapat meningkatkan pembelajaran IPA siswa kelas IV SDN Pancasila kecamatan Lembang kabupaten Bandung barat.

\section{Simpulan}

Berdasarkan hasil penelitian tindakan kelas yang dilakukan pada mata pelajaran IPA di SDN Pancasila adalah sebagai berikut:

1. Perencanaan pembelajaran IPA menggunakan model learning cycle 5E dirumuskan dalam RPP. Dalam RPP, setiap tujuan pembelajaran dirumuskan dengan melibatkan siswa secara langsung pada setiap tahapan pembelajaran. adapun tahapan pembelajaran pada RPP diantaranya yaitu, pada fase engage dilakukan kegiatan tanya jawab untuk menggali pengetahuan awal siswa, menyajikan fenomena dengan menampilkan gambar atau video, siswa penyampaian prediksi. Pada fase explore dilakukan kegiatan percobaan, siswa 
melakukan pengamatan dan mencatat hasil pengamatan. pada fase explain, dilakukakan kegiatan presentasi hasil pengamatan dan diskusi. Sedangkan pada fase extend guru menjelaskan pengembangan konsep dalam kehidupan sehari-hari. Pada kegiatan akhir yaitu pada fase evaluate, dilakukan kegiatan refleksi terhadap pembelajaran, penyimpulan materi ajar, dan mengadakan tes tertulis. Penilaian proses direncanakan dilakukan dengan menggunakan lembar observasi penilaian kinerja.

2. Pelaksanaan pembelajaran IPA dengan menggunakan model learning cycle $5 E$. Pada fase engage siswa melakukan kegiatan tanya jawab terhadap gambar dan video dan menyampaikan prediksi. Pada fase explore siswa melakukan kegiatan percobaan, melakukan pengamatan dan mencatat hasil pengamatan. Pada fase explain siswa melakukan diskusi dan presentasi hasil pengamatan. Pada fase extend, siswa memperhatikan penjelasan guru dan menjelaskan kembali pengembangan konsep. Dan yang terakhir pada fase evaluate, siswa menyimpulkan materi ajar dan melaksanakan evaluasi dengan menjawab soal.

3. Pembelajaran meningkat setelalah diterapkannya model learning cycle $5 E$. Peningkatan pembelajaran tercermin dari peningkatan proses dan hasil belajar. Peningkatan proses pembelajaran jelas terlihat dari dari peningkatan aktivitas siswa, sedangkan peningkatan hasil belajar siswa terlihat dari peningkatan jumlah siswa tuntas baik pada tes kognitif maupun pada penilaian kinerja.

\section{DAFTAR PUSTAKA}

Badan Standar Nasional Pendidikan.(2006). Panduan Penyusunan Kurikulum Tingkat Satuan Pendidikan Jenjang Pendidikan Dasar dan Menengah.Jakarta: BSNP.
Dahar, Ratna Wilis.(1989). Teori-teori Belajar. Jakarta: Erlangga

Destyanti, dewi.(2011). Penerapan modl learning cycle 5Euntuk meningkatkan hasil belajar siswa dalam pembelajaran fisika. Bandung: Tidak diterbitkan

Dimyati dan Mudjiono (2006).Belajar dan Pembelajaran. Jakarta: Rineka Cipta.

Fajaroh, Fauziatul. (2008). Pembelajaran Dengan Model Siklus Belajar (Learning Cycle)[ Online]. Tersedia: http://massofa.wordpress.com/2008/01/ 06/pembelajaran-dengan-model-siklusbelajar-learning-cycle/[ 170311]

Lorsbach, Antony. W. (2006).The learning cycle as a tool for planing science instruction.[Online]. Tersedia: http://www.ilstu.edu/scienceed/lorsbac h/257lrcy.htm. [ 170311]

Mulyasa, E. (2005). Implementasi Kurikulum 2004 Panduan Pembelajaran KBK. Bandung: Rosdakarya

Nasution.(2000). Berbagai Pendekatan Dalam Proses Belajar Mengajar. Jakarta:Bumi aksara

Rakhmat, et al. (2006) . Psikologi Pendidikan. Bandung: UPI Pres.

Rustaman, N. et al. (2003). Strategi Belajar Mengajar Biologi. Malang: Universitas Negeri Malang.

Sagala, syaiful.(2010). Konsep dan Makna Pembelajaran. Bandung: Alfabeta

Suparno, paul. (1997). Filsafat Konstruktivisme Dalam Pendidikan. Yogyagarta: kanisius

Syah.(2002). Psikologi Pedidikan Dengan Pendekatan Baru. Bandung: Remaja rosdaya karya. 
Trianto.(2010). Model Pembelajaran

Terpadu.Jakarta: Bumi Aksara.

Usman, Moh. Uzer.(2006). Menjadi Guru Profesional.Bandung: PT. Remaja Rosdakarya

Winkel,W.S.(1996). Psikologi Pengajaran. Jakarta:Grasindo.

Wiriaatmadja, Rochiati. (2005). Metode Penelitian Tindakan Kelas.Bandung: Remaja rosdakarya

Yuliani. (2006). Penerapan modelsiklus belajar(learning cycle)tipe $5 E$ terhadap peningkatan hasil belajar dalam aspek keterampilan berfikir rasional fisika siswa SMA. Bandung. Tidak diterbitkan.

[Online].Tersedia: http://edukasi.kompasiana.com/2010/ 10/15/pendidikan-budaya-danentrepreneurship/[ 120411] 